ELORE (ISSN 1456-3010), vol. $16-2 / 2009$.

Julkaisija: Suomen Kansantietouden Tutkijain Seura ry.

[http://www.elore.fi/arkisto/2_09/kirjallisuus_lukin_2_09.pdf]

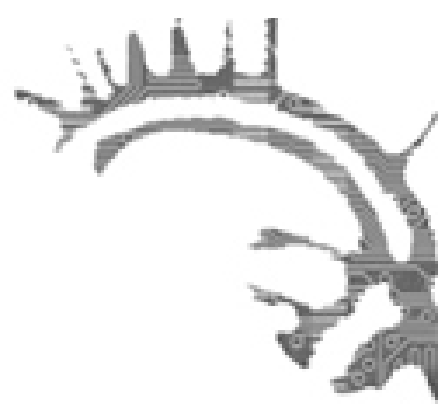

\title{
KiRJA-ARVIO:
}

\section{ISON KARHUN VIERELLÄ}

Salminen, Timo 2008: Aatteen tiede. Suomalais-Ugrilainen Seura 1883-2008. Suomalaisen Kirjallisuuden Seuran Toimituksia 1172. Helsinki: SKS. 282 sivua.

\section{$\underline{\text { Karina Lukin }}$}

Suomalais-Ugrilainen Seura (jatkossa SUS), yksi Suomen vanhimmista tieteellisistä yhdistyksistä, juhli vuonna 2008 125-vuotista historiaansa. Juhlintaan kuului kaksi seminaaria, joista ensimmäisessä käsiteltiin SUS:n piirissä tehtyjä kenttätöitä sekä niiden aineistojen jalostumista tiedoksi. Toinen seminaari käsitteli moniaalle ulottuvaa suomalais-ugrilaisen kieliyhteisön verkostoa. Kulttuurien museon näyttely Castrénin saappaissa, joka kertoi suomalaisten tutkimusmatkoista Euraasiassa, oli niin ikään Seuran juhlavuoden kunniaksi pystytetty. Seuran historiikki oli olennainen osa juhlintaa. Historiikille lienee tarvettakin, sillä tätä aikaisemmin olemassa oli ainoastaan lyhyehkö yleiskatsaus (Suhonen 1983) ja suomalaisen fennougristiikan "sankariajasta" on kulunut jo sangen kauan: muistitieto ei ole enää kulkeutunut nuorimmille sukupolville ja etäisyyden ottaminenkin oli nyt luontevaa. Seuran historiaa kirjoittamaan pestattiin Timo Salminen, jonka väitöskirja (2003) käsitteli suomalaisen, Venäjälle ja Siperiaan suuntautuneen arkeologian historiaa. Esipuheessa Salminen valittelee kirjoittaneensa Seuran historiikkia kovassa kiireessä, mutta on silti onnistunut laatimaan koherentin kuvauksen SUS:n menneisyydestä.

\section{Hyvässä SEURASSA}

SUS perustettiin "kieli-, muinais- ja kansatiedettä sekä muinaishistoriaa varten." vuonna 1883 Otto Donnerin aloitteesta. Tarkoituksena oli perustaa järjestö, jonka puitteissa voitaisiin Suomessa jatkaa Castrénin aloittamaa "suomen suvun tutkimus- 


\section{KARINA LUKIN}

työtä’, jolla viitattiin etenkin aineiston hankintaan suomalais-ugrilaisia ja altailaisia kieliä puhuvien parissa. Kuten Salminen kirjassaan kuvaa, Seuran perustamista leimasi niin kulttuurinationalismi, kosmopolitismi, romantiikka kuin evolutionismikin, mikä kuvastaa ajalle ominaista aatteellisten virtausten runsautta. 1800-luvun loppu oli niin ikään kiivaiden väittelyiden aikaa, mutta Donner onnistui kokoamaan yhteisen hankkeen taakse vakuuttavan joukon suomalaisia tutkijoita, poliitikkoja, liikemiehiä ja muita vaikuttajia.

SUS:n johtokunnan kokoonpano vilisi vastakin suomalaisen kansallisen tiede-elämän johtohahmoja, joiden toiminta ulottui myös muihin tieteellisiin ja kulttuuriseuroihin. Aktiivijäsenistö on ollut toimelias myös kansallisessa, joskus jopa kansainvälisessä politiikassa sekä poliittisissa järjestöissä. Kaiken kaikkiaan SUS, muiden alan tieteellisten yhdistysten rinnalla, on ollut jäsenistönsä kautta varsin korkea-arvoinen seura. Salmisen kirja vahvistaa kuvaa siitä, että pienessä maassa kulttuuri- ja perinnetieteiden politiikkaa on harjoittanut rajallinen ihmisjoukko, jonka voimavarojen on pitänyt riittää moniaalle: esimerkiksi Suomalaisen Kirjallisuuden Seurassa ja Suomalaisessa Tiedeakatemiassa oli pitkään yksi tai useampi niin sanottu SUS:n edustaja. Vastaavasti Seuraan on yritetty vuosikymmenten aikana haalia jäsenistöä arvokkaista tai vaikutusvaltaisista piireistä uskottavuuden ylläpitämiseksi. Vaikutusvallan sukupuolittumisesta ja myös kansallisten tieteiden historiasta kertoo jotain se, että SUS:n johtokunnassa tavattiin nainen ensimmäistä kertaa vuonna 1988 ja ensimmäinen naisesimies saatiin vasta vuonna 2001, jolloin nykyinen esimies Ulla-Maija Kulonen astui ruoriin. Tällä hetkellä johtokunnassa istuu kuusi naista ja kolme miestä.

Koska Salminen kuvailee tällaisen mahdikkaan joukon toimintaa, historiikista on tullut visuaalisesti melko pompöösi: sen lukuisat valokuvat esittelevät arvovaltaisia miehiä tummissa puvuissaan milloin valokuvausstudioissa, milloin illallispöytien äärellä. Nämä kuvat asettuvat mukavaan kontrastiin lukuisten kenttätöistä kertovien kuvien kanssa, joissa tutkijatkaan eivät viitsi niin pönöttää - sen sijaan tutkittavien suhde kameraan ei ole selkeästikään ollut yhtä ongelmaton. Kirjan kansikuva tuo avoimesti esiin kenttätöissä esiintyvän tutkijan ja tutkittavan välisen vuorovaikutuksen epäsuhdan: siinä ylioppilaslakkiin ja reissussa rähjääntyneisiin puvun takkiin, kauluspaitaan, tummiin housuihin ja saappaisiin pukeutunut biologi ja heimoaktivisti Herman Stenberg on kääntynyt vieressään istuvaa 15 -vuotiasta hantityttöä kohti tuijottaen tätä (alaspäin) avoimen tutkivasti. Tyttö on kääriytynyt vaatteidensa sisään katsekontaktia vältellen. Suomalaistenkin suhde tutkittaviinsa on ollut ongelmallinen, vaikka tutkijat pitkään ajattelivat menevänsä tutkimaan "meitä". Suomalaiset kohtasivat alusta alkaen epäluuloja ja muita tavanomaisia kenttätyöhön kuuluvia vierauden aiheuttamia vaikeuksia etenkin uskonnollista tietoa kerätessään. Ironista on, että paikalliset pitivät venäläisiä ja venäläisyyttä halveksivia suomalaisia tutkijoita useimmiten venäläisinä (s. 33). Kulttuurierojen lisäksi tutkijan ja tutkittavien välillä oli myös luokkaero. 
ISON KARHUN VIERELL̈̈

\section{AATTEEN TIEDE ELI TASAPAINOILUA TIETEELLISEN TEHTÄVÄN JA HEIMOTUNTEEN RAJOILLA}

Historiikki on jaettu seitsemään päälukuun, jotka kuvaavat kronologisesti SuomalaisUgrilaisen Seuran perustamista, alkutaipaleen vaikeuksia, kausia Otto Donnerin ja E. N. Setälän johdossa sekä sotien jälkeisten vuosikymmenten vakiintumiskehitystä ja Neuvostoliiton hajoamista seuraavia vuosia. Tämä karkea jaottelu toimii hyvin sen avulla Seuran historia rytmittyy mielekkäällä tavalla. Sen sijaan päälukujen alla teksti puuroutuu välillä yksityiskohtien vyörytyksessä niin, että lukijan on vaikea pysyä perässä, kuka sanoi tai kirjoitti kenelle ja ennen kaikkea miksi. Näin on etenkin, kun Salminen kuvaa 1900-luvun alun vilkasta toimintaa ja keskustelua. Ehkä kirjoittajan kiire on ollut syynä sille, etteivät kaikki asiat ole hahmottuneet relevanteiksi kokonaisuuksiksi vaikka ne onkin haluttu tuoda esiin. Ajoittainen epäselvyys ei kuitenkaan vähennä sitä arvoa, joka yksityiskohtien esilletuomisella on: kirja on täynnä kiehtovia kädenvääntöjä ja historiallisia sattumia.

Osittain kyse on siitä, että Salminen ei ole rohjennut tehdä voimakkaita tulkintoja, minkä vuoksi hän on päätynyt ainoastaan luettelemaan Seuran tukemaa tutkimustoimintaa, rahanhaku ja -jakotoimenpiteitä, aloitteita ja suhteita lähiseuroihin. Erityisen varovainen Salminen on ollut tehdessään tulkintoja Suomalais-Ugrilaisen Seuran poliittisuudesta, jonka kieltäminen toistuvuudessaan tuntuu olevan kirjan perustavia juonteita. Lukijalle tulee hyvin selväksi, että vaikka seuran aktiivijäsenet kuuluivat milloin mihinkin radikaaliin järjestöön tai liikehdintään, seura itse pysyi näiden ulkopuolella ja keskittyi tieteelliseen toimintaan. Näiden tulkintojen varovaisuus on hämmästyttävää, kun Salminen yhtä äkkiä tulkitsee Kanniston puhetta rivien välistä niin, että Paasosen ja Krohnin ylistäminen on E. N. Setälän parjaamista (s. 137). Tulkinta saattaa olla oikeakin, mutta se on kirjan muihin tulkintoihin verrattuna hämmästyttävän rohkea.

Toisaalta kirjan nimi Aatteen tiede antaa ymmärtää, että Seuran toiminnan taustalla olevan tieteen kenttään on kuulunut aate, joka kirjassa nimetään muun muassa kulttuurinationalismiksi ja heimoaatteeksi. Heimoaate onkin seurannut toimintaa pidempään kuin kulttuurinationalismi, joka on Suomen itsenäistymistä seuranneiden vuosikymmenten jälkeen jäänyt taustalle, pelkäksi retoriikaksi (s. 157). Suomalais-ugrilaisten kansojen yhtenäisyyttä ja keskinäistä apuakin korostava heimoaate tulee esiin tuon tuostakin Salmisen historiikissa, erityisesti ensimmäisen ja toisen maailmansodan välimaastoa kuvaavassa jaksossa, "Heimoseura 1919-1944". Heimoaate on kuitenkin ollut läsnä aina: esimerkiksi vuosien 1900 ja 1901 vaihteessa Seuran johdossa olleet "Setälä, Paasonen ja Wichmann tasapainoilivat tieteellisen tehtävänsä ja heimotunteen rajoilla" toimiessaan sukukansojen edustajien neuvonantajina, avustajina ja puolestapuhujina. Edustajia ei koulutettu ainoastaan aineistojen kerääjiksi, vaan heidän toivottiin omaksuvan myös oman kansansa sivistäjän rooli (s. 91-94). Kuten jo todettua, Seura ei julkisesti toiminut koskaan näin poliittisesti, mikä ei estänyt venäläisiä viranomaisia huomaamasta, että tutkijoiden mukana ja jäljessä kulki aate, jonka tarkoitus oli vaikuttaa tutkittaviin. Näin ei olekaan mikään ihme, että venäläiset tahot ovat aika ajoin suhtautuneet hyvin epäilevästi Seuran stipendiaattien toimintaan. Puolueettomuuden 


\section{KARINA LUKIN}

linja ei ole aina ollut kovin uskottava. Sittemmin heimoaatteen ongelma on koetettu ratkaista luomalla M. A. Castrénin seura, jolla on Suomen valtion tuki ja jonka hallituksen jäsenistä kolme istuu myös SUS:n johtokunnassa. Suomi on edelleen pieni maa ja heimoaatteella on sijansa tutkijoiden parissa.

\section{VAikea Venäjä}

Salminen asettaa SUS:n toiminnan pääasiassa yleiseen poliittisen historian kontekstiin, jolloin Seurankin toiminnan poliittisuus, vaikka se ei avointa ollutkaan, tulee esiin. Tieteellisen seuran toimintaa olisi mielestäni voinut tarkastella voimakkaammin myös tieteenhistoriallisessa kontekstissa, vaikka epäilemättä Setälän järäpäisesti puolustama paradigma olisi saanut silloin luonnottoman paljon tilaa. Folkloristia esimerkiksi jää vaivaamaan kysymys, miksi kielitiede vähitellen 1920-luvulta alkaen sai niin voimakkaan painotuksen Seurassa, jonka ydinajatus on ollut kirkkaan holistinen ja jonka piirissä kerätyt aineistot tarjoaisivat edelleen huimia mahdollisuuksia folkloristiikalle. Poliittis-historiallinen tulkinta ei myöskään tee aina oikeutta tutkijoille: Salmisen mukaan Julius Krohnin venäläisiä loitsurunoja käsitellyt esitelmä henki SUS:n yleistä aatteellista asennoitumista väittäessään, ettei venäläisillä runoilla ole ollut mitään vaikutusta suomalaisiin loitsuihin (s. 29-30). Vaikka en ole Krohnin esitelmää lukenutkaan, tuntuu Salmisen tulkinta tässä kohdin hieman liian poliittiselta: Krohn tunnisti muussa runoudessa slaavilaisia vaikutteita, mutta piti loitsurunoutta niin myöhäisenä ja improvisoituna, että siinä ei kenties ollut edes mahdollista nähdä minkään muun runouden vaikutusta (esim. Hautala 1958, 187-189; 220).

Salminen olettaakin, että Julius Krohn on esitelmässään haluton näkemään venäläisvaikutteita, koska kansallisten tieteiden suhde venäläisiin vaikutteisiin on ollut ajoittain vaikea. Suhde Venäjään ja venäläisiin on ylipätänsä hallinnut SUS:n menneisyyttä, vaikka alusta asti toiminnan kansainvälistä luonnetta onkin korostettu. Venäjä on ollut historian kulussa arvaamaton, mutta sen oikkuihin on sopeuduttu. Tutkijoille venäläisyys on usein ollut välttämätön paha ja taustatekijä, jota ei ole haluttu ottaa osaksi tutkittavien ilmiöiden kenttää. Siksi onkin lähinnä paljastavaa, että Venäälllä tai Neuvostoliitolla on ollut niin suuri rooli Seuran historiassa. Venääään on suhtauduttu joskus myös sinisilmäisesti, mikä on valitettavasti todettavissa ainoastaan jälkikäteen. Seuran mustaa historiaa ovat luvut siitä, mitä tapahtui niille kielenoppaille tai yhteistyökumppaneille, joita saatiin neuvostoaikoina Suomeen joko sotavankeina tai vierailijoina ja niille aktivisteille, jotka jatkoivat kontaktejaan Neuvostoliiton syntymisen jälkeenkin. Esimerkiksi komilainen Vasili Lytkin vangittiin 1930-luvulla ja tuomittiin kuulumisesta Suomalaisten kansojen vapautuksen taisteluliittoon sekä Suur-Suomea ja aseellista vallankumousta Komissa tavoittelevaan SUS:an. Hän vietti työleirillä kolme vuotta ja sai palata Komiin vasta 1957. Vastaavista syistä myös teloitettiin ihmisiä. Seurassa (ja Suomessa) oltiin autuaan tietämättömiä Neuvostoliiton toiminnasta: Lytkiniä ehdotettiin 1950-luvulla tutkijavierailijaksi, mikä ei tietenkään sopinut neuvostoviranomaisille. 
Venäjä ja venäläiset ovat olleet myös niin avoimen kuin peitellynkin vihan kohteita, mikä on sellainen historiallinen taakka, jota suomalais-ugrilaisten kielten ja puhujien tutkijoiden parissa ei ole vielä juurikaan avattu. Venäläisviha on ollut osa heimoaatetta, mutta se heijastuu esimerkiksi siihen, että kielten ja tapojen muutosta suomalais-ugrilaisten puhujien parissa kutsutaan edelleenkin venäläistymiseksi. Tutkijoiden parissa suhtautuminen muutokseen on vasta viime vuosina muuttunut monitahoisemmaksi: se ei enää ole ainoastaan pahasta. Salmisen kirja avaa hienosti ja vaivihkaa myös tätä venäläisten vihaamisen perinnettä, jonka tosin toivoisi jo murtuvan. Venäjä tuskin lakkaa olemasta.

\section{KiRjallisuUs}

HAUTALA, JOUKO 1954: Suomalainen kansanrunoudentutkimus. Helsinki: SKS.

SALMINEN, TIMO 2003: Suomen tieteelliset voittomaat: Venäjä ja Siperia suomalaisessa arkeologiassa 1870-1935. Helsinki: Suomen muinaismuistoyhdistys.

SUHONEN, SEPPO 1983: Suomalais-ugrilaisen Seuran historiaa. - Korhonen, Mikko \& Suhonen, Seppo ja Virtaranta, Pertti, Sata vuotta suomen sukua tutkimassa. 100-vuotias suomalais-ugrilainen seura. Helsinki: Weilin+Göös.

Filosofian maisteri Karina Lukin valmistelee väitöskirjaa nenetsien perinteestä Helsingin yliopiston folkloristiikan oppiaineessa. 